\title{
Stress Degradation Behavior of Paliperidone, an Antipsychotic Drug, and Development of Suitable Stability-Indicating RP-LC Method
}

\author{
Sanjay A. Jadhav, ${ }^{1,2}$ Shashikant B. Landge, ${ }^{1}$ Pramod M. Choudhari, ${ }^{1}$ \\ Pavankumar V. Solanki, ${ }^{1}$ Saroj R. Bembalkar, ${ }^{2}$ and Vijayavitthal T. Mathad ${ }^{1}$ \\ ${ }^{1}$ Department of Research and Development, Megafine Pharma (P) Ltd., Nashik 422 202, India \\ ${ }^{2}$ Department of Chemistry, Deogiri College, Aurangabad 431 004, India \\ Correspondence should be addressed to Vijayavitthal T. Mathad, drvtmathad@yahoo.co.in \\ Received 9 February 2011; Accepted 5 April 2011 \\ Academic Editor: Wenkui Li
}

Copyright () 2011 Sanjay A. Jadhav et al. This is an open access article distributed under the Creative Commons Attribution License, which permits unrestricted use, distribution, and reproduction in any medium, provided the original work is properly cited.

\begin{abstract}
A new, simple, rapid, and stability-indicating reversed phase liquid chromatographic (RP-LC) method for the determination of both assay and related substances in paliperidone has been developed and validated. During the forced degradation at hydrolysis, oxidative, photolytic, and thermal stressed conditions, the degradation was observed in the oxidative and acid stress conditions. Five process-related impurities (Imp-A to Imp-E) in test sample of paliperidone have been detected using newly developed RP-LC method. Among the five, Imp-C and Imp-D were found to be degrdants. Good resolution between the peaks corresponding to degradation and process-related impurities from the analyte was achieved on a Hypersil BDS C18 $(250 \times 4.6 \mathrm{~mm}, 5 \mu \mathrm{m}) \mathrm{column}$. The stress samples were assayed against a qualified reference standard, and the mass balance was found to be close to $99.0 \%$. The method was validated as per ICH guideline and was found to be robust. The proposed RP-LC method was successfully applied to the analysis of commercial formulation and was found to be specific and selective.
\end{abstract}

\section{Introduction}

Paliperidone, a major metabolite of risperidone (9-hydroxyrisperidone), has been approved by the FDA for the treatment of schizophrenia since 2006. Paliperidone is a centrally active dopamine $\mathrm{D} 2$ and serotinergic $5-\mathrm{HT}_{2 \mathrm{~A}}$ antagonist. It is also active as an antagonist at $\alpha_{1}$ and $\alpha_{2}$ adrenergic receptors and $\mathrm{H}_{1}$-histaminergic receptors. Paliperidone has one chiral centre but as the pharmacological profiles of the racemate and the two enantiomers are similar with respect to in vitro binding assays, in vitro receptor occupancy studies and in vivo functional interaction studies, hence, it is marketed in its racemic mixture [1-8]. Paliperidone is chemically designated as $( \pm)-3$-[2-[4-(6-fluoro-1,2-benzisoxazol-3-yl)-1piperidinyl] ethyl]-6,7,8,9-tetrahydro-9-hydroxy-2-methyl4 Hpyrido[1,2-a]pyrimidin-4-one (Figure 1 ). It cor- responds to the molecular formula, $\mathrm{C}_{23} \mathrm{H}_{27} \mathrm{FN}_{4} \mathrm{O}_{3}$, and its relative molecular mass is 426.49 . The development of an accurate and efficient analytical method to determine the quality of the product is a critical activity during the process development of the product in generic companies as process is either improved continuously with the use of new reagents, intermediates, and so forth, or route of synthesis itself changes some time. During the study of synthetic process in our laboratory, we discovered five process-related impurities, namely, Imp-A, Imp-B, Imp-C, Imp-D, and Imp-E among them two impurities (Imp C and $\operatorname{Imp} D$ ) were found to be degradation-related as shown in Figure 1. The Imp-C was identified as metabolite (M-12) of paliperidone [9]. A literature survey revealed an HPTLC method for the determination of paliperidone in formulations and for in vitro release study [10]. Few other methods for the quantitative determination of risperidone and 9hydroxyrisperidone in biological samples have also been reported $[11,12]$. However, these papers were restricted to the determination of paliperidone and the details of processrelated impurities and degradation impurities formed under the stress conditions employed were not discussed. As per 


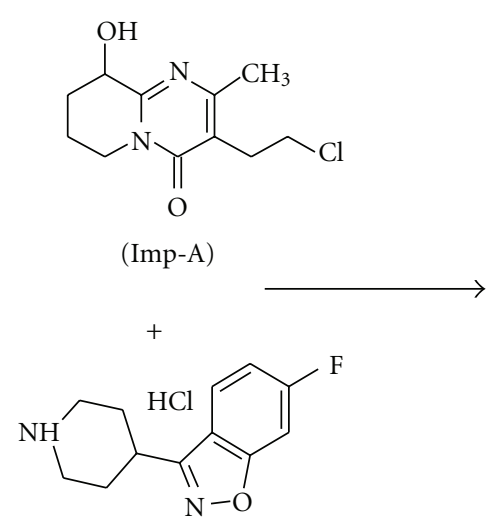

(Imp-B)

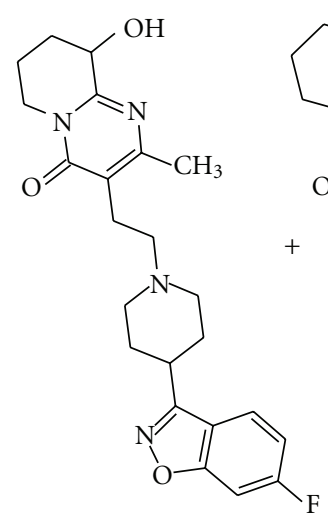

(Paliperidone)

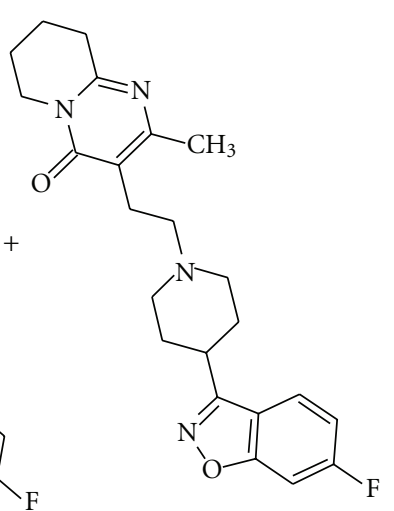

(Imp-E)<smiles>Cc1nc2n(c(=O)c1CCN1CCC(c3noc4cc(F)ccc34)CC1)CCCC2O</smiles>

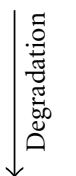

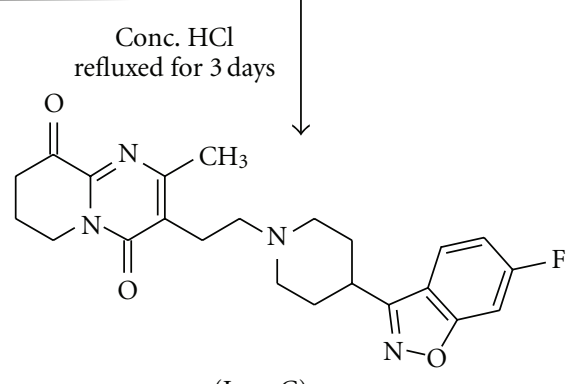

(Imp-C)

FIGURE 1: Synthetic scheme of paliperidone: generation of process-related impurities and degradation-related impurities.

the requirements of various regulatory authorities, the impurity profile study of drug substances and drug products has to be carried out using a suitable analytical method in the final product $[13,14]$. Further, paliperidone is not yet official in any of the pharmacopoeia.

To the best of our knowledge no method has been reported for the determination of paliperidone and its potential process related impurities in the bulk drug using HPLC for the regular analysis and stability studies in quality control laboratory. The core-objective of this research work is to develop a simple and rapid stability-indicating RP-LC method for the determination of process and degradation related substances in paliperidone bulk drugs and validation as per USP and ICH guidance documents $[15,16]$. All the impurities (Figure 1) were found to be present in the sample at levels below $0.1 \%$. All these identified impurities were received from megafine R\&D laboratory and characterized by IR, mass and NMR. The developed method was also selective and specific for the determination of paliperidone and related substances in pharmaceutical dosage forms.

\section{Experimental}

2.1. Chemicals. HPLC-grade acetonitrile and methanol procured from Merck (India) were used. Ammonium dihydrogen orthophosphate, hydrochloric acid, sodium hydroxide and hydrogen peroxide were all of AR grade, procured from Merck (India). HPLC-grade water obtained from Millipore system (Millipore Inc., USA) was used throughout the analysis. The investigated sample of paliperidone and its potential process and degradation-related impurities (Figure 1) were received from synthetic laboratory of Megafine Pharma ( $\mathrm{P}$ ) Ltd., Nashik, India.

2.2. HPLC (Analytical) Instrumentation and Operating Conditions. A Waters HPLC (Milford, MA, USA) equipped with Alliance 2695 separations module and 2996 photodiode array detector was used for method development, forced degradation studies, and method validation. The column Hypersil BDS C18 $(250 \mathrm{~mm} \times 4.6 \mathrm{~mm}, 5 \mu \mathrm{m})$ thermostated at $45^{\circ} \mathrm{C}$ was used for the separation. $0.05 \mathrm{M}$ ammonium dihydrogen orthophosphate buffer was prepared by dissolving $5.75 \pm 0.10 \mathrm{~g}$ ammonium dihydrogen orthophosphate in $1000 \mathrm{~mL}$ of water, filtered through $0.45 \mu \mathrm{m}$ membrane filter (Millipore PVDF) and degassed in ultrasonic bath prior to use as mobile phase A. Methanol was used as mobile phase $\mathrm{B}$. The flow rate and injection volumes were $1.0 \mathrm{~mL} \mathrm{~min}^{-1}$ and $20 \mu \mathrm{L}$, respectively. The analysis was carried out under gradient conditions as follows: time $(\mathrm{min}) / \mathrm{A}(\mathrm{v} / \mathrm{v}): \mathrm{B}(\mathrm{v} / \mathrm{v}) ; T_{0.01} / 68: 32, T_{10.0} / 68: 32, T_{25.0} / 50: 50$, $T_{27.0} / 68: 32$, and $T_{35.0} / 68: 32$. The data were acquired at $237 \mathrm{~nm}$ for $35 \mathrm{~min}$ and processed by use of Empower Pro 
data handling system. For the analysis of forced degradation samples, the photodiode array detector was used in the scan mode from $200 \mathrm{~nm}$ to $400 \mathrm{~nm}$. The peak homogeneity was expressed in terms of peak purity values.

2.3. Preparation of Solutions. A mixture of water and acetonitrile in the ratio of 50:50(v/v) was used as diluent in the preparation of analytical solutions. A solution of paliperidone was prepared at a concentration of $1000 \mu \mathrm{g} \mathrm{mL}^{-1}$ and $100 \mu \mathrm{g} \mathrm{mL}^{-1}$ in the diluent for related substances determination and assay determination, respectively. The individual stock solutions of each impurity at concentration about $150 \mu \mathrm{g} \mathrm{mL}^{-1}$ (for impurities Imp-A, Imp-B, Imp-D, and Imp-E) and $500 \mu \mathrm{g} \mathrm{mL}^{-1}$ (for impurity Imp-C) were also prepared in diluents, and those solutions were diluted further adequately to study the validation attributes. The specification limits used for validation studies were $0.5 \%$ for the related substance Imp-C and $0.15 \%$ for the remaining related substances, namely, Imp-A, Imp-B, Imp-D, and ImpE. Hence the system suitability solution of all impurities was prepared at specification level by diluting above stock solutions.

Formulation drug sample prepared as; ten weighed tablets of paliperidone (equivalent to $5 \mathrm{mg}$ each of paliperidone) were ground to powder and an equivalent of $25 \mathrm{mg}$ of active ingredient dissolved in diluent in a $25 \mathrm{~mL}$ volumetric flask, ultra sonicated for about $10 \mathrm{~min}$. and its volume made up to the mark with the diluent, filtered through Merck Nylon syringe filter having pore size $0.45 \mu \mathrm{m}$. The clear liquid was collected and used for the determination of related substances in the pharmaceutical dosage forms. This solution was ten-times diluted for the assay determination in pharmaceutical dosage forms.

2.4. Analytical Procedure. Paliperidone working reference standard solution $\left(1000 \mu \mathrm{g} \mathrm{mL}^{-1}\right)$ spiked with all impurities at a speification level $(\mathrm{w} / \mathrm{w})$ was used as resolution mixture solution (RMS). $10.0 \mu \mathrm{L}$ of blank, RMS, six replicate injections of system suitability solution, and test sample solution were separately chromatographed. A resolution of not less than 1.5 between paliperidone, and Imp-C was set as a system suitability requirement in RMS. The relative standard deviation (RSD) of not more than $5.0 \%$ for ImpA, Imp-B, Imp-C, Imp-D, and Imp-E peak areas obtained from six replicate injections of system suitability solution is used to verify the system precision. All the known related substances Imp-A, Imp-B, Imp-C, Imp-D and Imp-E in test sample were determined against mean area of respective impurities obtained from replicate injections of system suitability solution.

2.5. Procedure for Forced Degradation Study. The forced degradation studies were conducted on bulk drug substance in order to prove the stability-indicating property and selectivity of the established method [17]. Forced degradation of paliperidone drug substance was carried out under acid/base hydrolytic, oxidative, thermolytic, and photolytic stress conditions. Solutions were prepared by dissolving drug substance in diluent and then treating with concentrated hydrochloric acid (refluxed for 3-days), aqueous $1 \mathrm{M}$ sodium hydroxide (refluxed for $12 \mathrm{~h}$ ), and aqueous 15\% hydrogen peroxide (kept for $25 \mathrm{~min}$ at RT). After the degradation, these solutions were diluted with diluent and analyzed in the proposed method. For thermal stress, sample of drug substance was placed in a controlled temperature oven at $105^{\circ} \mathrm{C}$ for 8-days. For photolytic stress, the sample was exposed in photolytic conditions for 10 days as per ICH guideline. After the exposure to the above stress conditions, solutions of these samples were prepared by dissolving respective samples in diluent and diluted to the desired concentration and subjected for analysis using the proposed method. All the stressed samples were quantified for paliperidone and the impurities. Photodiode array detector was employed to check and ensure the homogeneity and purity of paliperidone peak in all the stressed sample solutions. Assessment of mass balance in the degraded samples was carried out to confirm the amount of impurities detected in stressed samples matches with the amount present before the stress was applied [18].

2.6. LC-MS Analysis. LC-MS analysis was carried out using triple quadrupole mass spectrometer (API 2000, PE SCIEX) coupled with a Shimadzu HPLC equipped with SPD 10A VP UV-vis detector and LC AT VP pumps (Foster city, CA, USA). Analyst software was used for data acquisition and data processing. The turbo ion spray voltage was maintained at $5.5 \mathrm{kV}$, and temperature was set at $375^{\circ} \mathrm{C}$. High pure nitrogen gas was used as auxiliary gas and curtain gas. Zero air was used as nebulizer gas. LC-MS spectra were acquired from $\mathrm{m} / \mathrm{z} 50$ to 800 in $0.1 \mathrm{amu}$ steps with $2.0 \mathrm{~s}$ dwell time. Paliperidone crude sample was subjected to LC-MS analysis. The analysis was carried out using a reversed phase column Kromasil C18, $250 \mathrm{~mm} \times 4.6 \mathrm{~mm}, 5 \mu \mathrm{m}$. Mobile Phase A was containing the mixture of buffer $(0.05 \mathrm{M}$ ammonium acetate) and methanol in the ratio of $85: 15 \mathrm{v} / \mathrm{v}$. The Mobile Phase B was containing buffer and methanol in the ratio of $35: 65 \mathrm{v} / \mathrm{v}$. Detection was carried out at $237 \mathrm{~nm}$, and flow rate was kept at $1.0 \mathrm{~mL} \mathrm{~min}{ }^{-1}$. Water and acetonitrile mixture in the ratio of $50: 50(\mathrm{v} / \mathrm{v})$ was used as diluent. Data acquisition time was $60 \mathrm{~min}$. The gradient program was as follows: time $(\mathrm{min}) / \mathrm{A}(\mathrm{v} / \mathrm{v}): \mathrm{B}(\mathrm{v} / \mathrm{v}) ; T_{0.0} / 100: 0, T_{5.0} / 100: 0$, $T_{35.0} / 0: 100, T_{50.0} / 0: 100, T_{51.0} / 100: 0$, and $T_{60.0} / 100: 0$. Four related substances were detected in the laboratory crude paliperidone batch sample. The masses of detected peaks were $243.1[(\mathrm{MH})+], 411.2[(\mathrm{MH})+], 443.1[(\mathrm{MH})+]$, and $425.1[(\mathrm{MH})+]$. Based on these mass values and synthetic scheme, the structures given in Figure 1 were suggested.

\subsection{Characterization of Impurities}

2.7.1. ${ }^{1} \mathrm{H}$ NMR Spectroscopy. The ${ }^{1} \mathrm{H}$ NMR spectra were recorded on Bruker $300 \mathrm{MHz}$ spectrometer using deuterated chloroform as solvent and tetramethylsilane (TMS) as internal standard.

2.7.2. Mass Spectrometry (MS). Mass spectra were recorded on Waters Micro mass-Quattro micro API mass spectrometer equipped with a quadrupole mass analyzer. Detection 
TABLe 1: Mass, FTIR spectral data, and 1H NMR chemical shift values.

\begin{tabular}{|c|c|c|c|}
\hline Name of impurity & $\begin{array}{l}\text { Mass value }(\mathrm{m} / \mathrm{z}) \\
(\mathrm{MH})+\end{array}$ & $\begin{array}{l}\text { FT-IR }(\mathrm{KBr}) \text { absorption } \\
\text { bands }\left(\mathrm{cm}^{-1}\right)\end{array}$ & $\begin{array}{l}{ }^{1} \mathrm{H} \text { NMR chemical shift values, } \delta \text { in } \mathrm{ppm} \text {, } \\
\text { (multiplicity, integration) }\end{array}$ \\
\hline (1) Imp-A & 210.6 & $\begin{array}{l}3145.80,2965.68,1664.21 \\
1531.82,1486.08 \\
1326.72,1183.89\end{array}$ & $\begin{array}{l}3.64-3.72(\mathrm{t}, 4 \mathrm{H}), 1.792-2.07(\mathrm{~m}, 4 \mathrm{H}) \\
4.43-4.45(\mathrm{bs}, 1 \mathrm{H}), 5.73(\mathrm{~s}, 1 \mathrm{H}) \\
2.28(\mathrm{~s}, 3 \mathrm{H}), 2.87-2.91(\mathrm{t}, 2 \mathrm{H})\end{array}$ \\
\hline (2) Imp-B & 221.5 & $\begin{array}{l}3057.86,2934.75,2500.67 \\
1612.45,1417.35,822.24\end{array}$ & $\begin{array}{l}7.69-7.73(\mathrm{dd}, 1 \mathrm{H}), 8.12-8.17(\mathrm{dd}, 1 \mathrm{H}) \\
7.29-7.36(\mathrm{td}, 1 \mathrm{H}), 3.50-3.55(\mathrm{~m}, 1 \mathrm{H}) \\
2.13-2.19(\mathrm{dd}, 4 \mathrm{H}), 3.02-3.11(\mathrm{dd}, 2 \mathrm{H}) \\
3.35(\mathrm{~m}, 1 \mathrm{H}), 9.30(\mathrm{~s}, 1 \mathrm{H})\end{array}$ \\
\hline (3) Imp-C & 425.2 & $\begin{array}{l}1721.52,1655.23,1608.81 \\
1519.39,1276.03,959.64\end{array}$ & $\begin{array}{l}2.20-2.27(\mathrm{~m}, 2 \mathrm{H}), 2.32-2.38(\mathrm{~m}, 4 \mathrm{H}) \\
2.41(\mathrm{~s}, 3 \mathrm{H}), 2.74-2.76(\mathrm{t}, 2 \mathrm{H}) \\
3.02-3.07(\mathrm{dd}, 2 \mathrm{H}), 3.14-3.23(\mathrm{~m}, 4 \mathrm{H}) \\
3.48(\mathrm{~s}, 1 \mathrm{H}), 3.73-3.76(\mathrm{t}, 2 \mathrm{H}) \\
4.02-4.06(\mathrm{t}, 2 \mathrm{H}), 7.31-7.38(\mathrm{td}, 1 \mathrm{H}) \\
7.72-7.75(\mathrm{dd}, 1 \mathrm{H}), 8.18-8.23(\mathrm{dd}, 1 \mathrm{H})\end{array}$ \\
\hline (4) Imp-D & 443.00 & $\begin{array}{l}3399.9,3054.70,1638.38 \\
1528.97,1474.56,1268.70 \\
1117.65,959.45\end{array}$ & $\begin{array}{l}7.30-7.36(\mathrm{td}, 1 \mathrm{H}), 8.01-8.04(\mathrm{dd}, 1 \mathrm{H}) \\
7.71-7.74(\mathrm{dd}, 1 \mathrm{H}), 1.78-2.03(\mathrm{~m}, 6 \mathrm{H}) \\
3.15-3.23(\mathrm{~m}, 4 \mathrm{H}), 3.33-3.41(\mathrm{~m}, 3 \mathrm{H}) \\
3.00-3.04(\mathrm{t}, 2 \mathrm{H}), 3.60-3.71(\mathrm{~m}, 1 \mathrm{H}) \\
3.89-3.95(\mathrm{td}, 1 \mathrm{H}), 2.60-2.70(\mathrm{~d}, 2 \mathrm{H}) \\
4.45(\mathrm{~s}, 1 \mathrm{H}), 2.29(\mathrm{~s}, 3 \mathrm{H}), 5.98(\mathrm{~s}, 1 \mathrm{H})\end{array}$ \\
\hline (5) Imp-E & 411.00 & $\begin{array}{l}3059.07,2942.22,2757.28 \\
1651.47,1610.70,1591.93 \\
1536.55,1270.52,958.74\end{array}$ & $\begin{array}{l}7.00-7.05(\mathrm{td}, 1 \mathrm{H}), 7.67-7.70(\mathrm{dd}, 1 \mathrm{H}) \\
7.20-7.23(\mathrm{dd}, 1 \mathrm{H}), 3.01-3.08(\mathrm{q}, 1 \mathrm{H}) \\
2.04-2.10(\mathrm{~m}, 4 \mathrm{H}), 2.23-2.27(\mathrm{td}, 2 \mathrm{H}) \\
2.50-2.54(\mathrm{dd}, 2 \mathrm{H}), 2.73-2.77(\mathrm{dd}, 2 \mathrm{H}) \\
3.14-3.17(\mathrm{t}, 2 \mathrm{H}), 2.83-2.86(\mathrm{t}, 2 \mathrm{H}) \\
3.89-3.92(\mathrm{~s}, 2 \mathrm{H}), 1.84-1.89(\mathrm{~m}, 2 \mathrm{H}) \\
1.91-1.96(\mathrm{~m}, 2 \mathrm{H})\end{array}$ \\
\hline
\end{tabular}

$\mathrm{s}$, singlet; $\mathrm{m}$, multiplet; $\mathrm{t}$, triplet; $\mathrm{d}$, doublet; td, triplet of doublet; q, quartet; bs, broad singlet.

of the ions was performed in electron spray ionization with positive ion mode. Spectra were acquired from $\mathrm{m} / \mathrm{z} 60$ to 800 in 0.1 amu steps with 10 numbers of scans.

2.7.3. Fourier Transform Infrared Spectroscopy (FT-IR). FTIR spectra were recorded for all the five degradation and process-related impurities (Table 1) on Perkin Elmer modelspectrum one instrument using $\mathrm{KBr}$ pellet method.

2.8. Synthesis of Paliperidone. The reaction scheme for the synthesis of paliperidone is shown in Figure 1 [19].

\section{Results and Discussion}

3.1. Detection of Impurities. Laboratory batches of crude paliperidone were analyzed for their related substances identification using the developed RP-HPLC method. These samples were subjected to LC-MS analysis. Based on the observed mass, starting material and reactants used in the synthetic scheme (Figure 1) the possible structures for related substances were assigned. The impurities (Imp-A, Imp-B, Imp-C, Imp-D, and Imp-E) were synthesized and coinjected with paliperidone to confirm the retention times. All the related substances were well resolved from each other and the representative chromatogram of spiked test preparation is shown in Figure 2. Among the identified impurities, Imp$\mathrm{A}$ and Imp-B, the key starting materials in the process; Imp$\mathrm{C}$ and Imp-D are the process as well as degradation related impurity, Imp-E is a process related impurities (Figure 1).

3.2. Structural Elucidation. All impurities (Imp-A, Imp-B, Imp-C, Imp-D, and Imp-E) were characterized with the help of MS, FT-IR, and NMR spectroscopic techniques. The mass, FT-IR spectral data, and ${ }^{1} \mathrm{H}$ NMR chemical shift values of these impurities are presented in Table 1.

3.3. Development of Chromatographic Conditions. The present study aims to develop the chromatographic system capable of eluting and resolving paliperidone, its process related and degradation related impurities (Imp-A, Imp-B, Imp-C, Imp-D, and Imp-E) within the short run time and that complies with the general requirement of system suitability. The Imp-C and Imp-D were the degradation impurities as well as process related impurities present in bulk samples produced in the process of paliperidone. The core objective of the chromatographic method is to get 


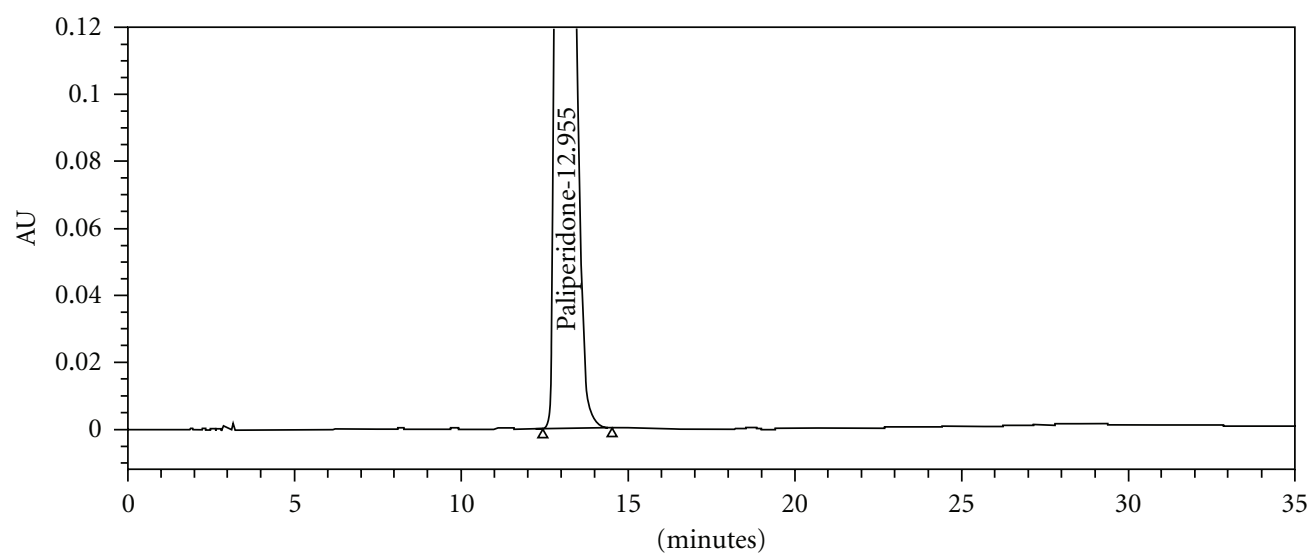

(a) Unspiked test sample

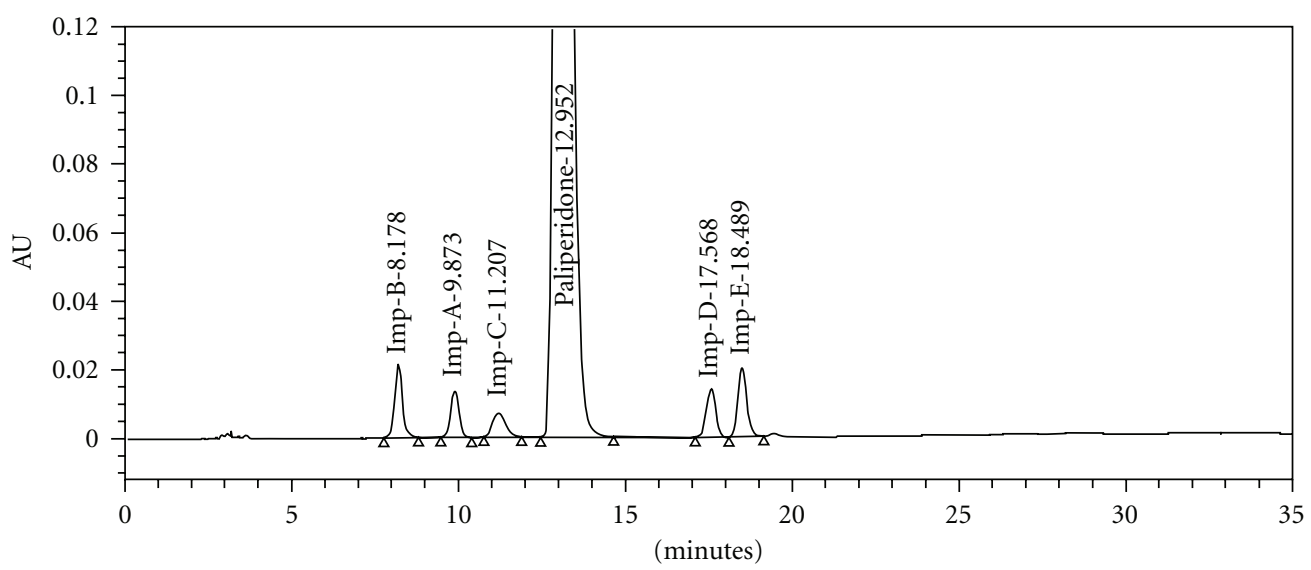

(b) Spiked test sample

FIGURE 2: Typical RP-HPLC chromatograms of (a) paliperidone unspiked test preparation and (b) paliperidone spiked test preparation with known impurities (Imp-A, Imp-B, Imp-C, Imp-D, and Imp-E).

the better peak shape of the paliperidone and its impurities along with the separation of closely eluting peak pairs of paliperidone and Imp-C.

The preliminary investigations were conducted for the effect of various parameters on system suitability of the method. The parameters assessed include the detection wavelength, the type and quantity of organic modifier, the column, the salt concentration, the $\mathrm{pH}$ of mobile phase and column temperature. Paliperidone has UV-absorption maxima at about $237 \mathrm{~nm}$ wavelengths. Hence detection at $237 \mathrm{~nm}$ was selected for method development purpose. Considering the fact that the dissociation constants of paliperidone are $\mathrm{pKa} 1=8.2$ (piperidine moiety) and $\mathrm{pKa} 2=2.6$ (pyrimidine moiety) [8], the method development attempts were made in acidic mobile phase $[20,21]$. The blend of the degradation product and potential impurities were used to optimize the method. The first trial was carried out on an isocratic condition by using reversed phase C18 column (Kromasil, $5 \mu \mathrm{m}, 250 \times 4.6 \mathrm{~mm}$ ) and a mixture of acetonitrile-buffer $\left(0.05 \mathrm{M} \mathrm{NH}_{4} \mathrm{H}_{2} \mathrm{PO}_{4}, \mathrm{pH} 5.5\right)$ in the ratio of $60: 40 \mathrm{v} / \mathrm{v}$. The system was found not suitable to separate the paliperidone and its impurities, where the peak of paliperidone was eluted very rapidly. As a means to increase the retention time, the percentage of acetonitrile in the mobile phase decreased from 60 to 20\%. The result of this change showed that the retention time of paliperidone was not increased more but tailing factor was too high, and the paliperidone and Imp$\mathrm{C}$ was coeluted. However, the increase of the modifier ratio was associated by a decrease in the retention times of all the compounds. By replacing the acetonitrile organic modifier, with methanol associated by a high tailing factor and longer retention times. Therefore, further method development trials were performed on gradient mode. All the impurities and paliperidone were subjected to separation using gradient RP-LC on different columns (Kromasil C18, SB-Phenyl, Inertsil ODS, and Hypersil BDS C18) using different buffer (phosphate, acetate and formate) and organic modifier (acetonirile and methanol). Finally, satisfactory peak shape and the resolution of closely eluting potential impurity were achieved on a Hypersil BDS C18 column $(250 \times 4.6 \mathrm{~mm}$ and $5.0 \mu \mathrm{m}$ particle size), by using $0.05 \mathrm{M} \mathrm{NH}_{4} \mathrm{H}_{2} \mathrm{PO}_{4}$ as a mobile phase-A and methanol as a mobile phase- $\mathrm{B}$. The flow rate of the mobile phase was $1.0 \mathrm{~mL} \mathrm{~min}^{-1}$. The gradient program also played a vital role in the separation of all the analyte peaks (Imp-A, Imp-B, Imp-C, Imp-D, Imp-E and paliperidone) within the short time. The HPLC gradient 
TABLE 2: System suitability test results.

\begin{tabular}{|c|c|c|c|c|}
\hline Compound & Resolution $\left(R_{\mathrm{s}}\right)$ & USP tailing factor $(T)$ & RRT & $\mathrm{RF}$ \\
\hline Imp-B & - & 1.13 & 0.63 & 0.96 \\
\hline Imp-A & 4.04 & 1.06 & 0.76 & 1.50 \\
\hline Imp-C & 2.39 & 1.11 & 0.87 & 1.76 \\
\hline Paliperidone & 2.06 & 1.17 & 1.00 & 1.00 \\
\hline Imp-D & 7.19 & 1.06 & 1.37 & 1.12 \\
\hline Imp-E & 2.15 & 1.17 & 1.43 & 0.96 \\
\hline
\end{tabular}

RRT, relative retention time; RF, response factor.

TABLE 3: Forced degradation results.

\begin{tabular}{|c|c|c|c|c|c|}
\hline \multirow{2}{*}{ Stress condition } & \multirow{2}{*}{$\%$ assay of paliperidone } & \multirow{2}{*}{$\%$ of degradant } & \multirow{2}{*}{ Observation and Mass balance } & \multicolumn{2}{|c|}{ Peak purity } \\
\hline & & & & PA & PT \\
\hline Undegraded & 99.70 & & - & 0.080 & 0.258 \\
\hline $\begin{array}{l}\text { Acid hydrolysis (conc. } \mathrm{HCl} \text {, } \\
4 \mathrm{~h} \text { refluxed) }\end{array}$ & 74.83 & 25.13 & $\begin{array}{l}\text { Increase in levels of Imp-A }(1.25 \%) \\
\text { and Imp-C }(13.01 \%) \text { and other } \\
10.88 \% \text { of unknown degradation } \\
\text { product formed (mass balance: } \\
99.96 \%)\end{array}$ & 0.226 & 0.251 \\
\hline $\begin{array}{l}\text { Base hydrolysis } \\
\text { ( } 5 \mathrm{M} \mathrm{NaOH}, 48 \text { h refluxed) }\end{array}$ & 88.59 & 11.05 & $\begin{array}{l}\text { Increase in levels of Imp-A }(0.31 \%) \text {, } \\
\text { Imp-B }(1.69 \%) \text { and other } 7.82 \% \text { of } \\
\text { unknown degradation product } \\
\text { formed (mass balance: } 99.00 \%)\end{array}$ & 0.195 & 0.248 \\
\hline $\begin{array}{l}\text { Oxidation }\left(6 \% \mathrm{H}_{2} \mathrm{O}_{2} \text { at }\right. \\
\text { RT) }\end{array}$ & 72.11 & 27.77 & $\begin{array}{l}\text { Increase in levels of Imp-A }(0.14 \%) \\
\text { and major degradation product, } \\
\text { that is, Imp-D }(24.51 \%) \text { and other } \\
3.12 \% \text { of unknown degradation } \\
\text { product formed (mass balance: } \\
99.64 \% \text { ) }\end{array}$ & 0.079 & 0.250 \\
\hline Thermal $\left(60^{\circ} \mathrm{C}, 8\right.$-days $)$ & 99.85 & Nil & $\begin{array}{l}\text { No any known and unknown } \\
\text { degradation product formed (mass } \\
\text { balance: } 100.3 \% \text { ) }\end{array}$ & 0.078 & 0.258 \\
\hline Photolytic as per ICH & 99.63 & Nil & $\begin{array}{l}\text { No any known and unknown } \\
\text { degradation product formed (mass } \\
\text { balance: } 99.2 \% \text { ) }\end{array}$ & 0.080 & 0.258 \\
\hline
\end{tabular}

Mass balance $=\%$ assay $+\%$ sum of all impurities $+\%$ sum of all degradants. PA, purity angle; PT, purity threshold.

program was optimized as follows: time $(\mathrm{min}) / \mathrm{A}(\mathrm{v} / \mathrm{v}): \mathrm{B}$ $(\mathrm{v} / \mathrm{v}) ; T_{0.01} / 68: 32, T_{10.0} / 68: 32, T_{25.0} / 50: 50, T_{27.0} / 68: 32$ and $T_{35.0} / 68: 32$. The column oven temperature was maintained at $45^{\circ} \mathrm{C}$ with $\mathrm{PDA}$ detector set at $237 \mathrm{~nm}$. The higher column temperature in the procedure evidenced the related substances and paliperidone were stable throughout the column separation process. In the optimized conditions it was observed that paliperidone, Imp-A, Imp-B, Imp-C, Imp$\mathrm{D}$ and Imp-E were well separated with a resolution greater than 2.0. A typical retention time of Imp-B, Imp-A, ImpC, paliperidone, Imp-D and Imp-E were about 8.18, 9.87, $11.21,12.95,17.57,18.49$, and $18.49 \mathrm{~min}$, respectively shown in Figure 2(b). The system suitability results are shown in Table 2 and the developed HPLC method was found to be specific for paliperidone, its process related impurities, and its degradation impurities (Figure 3). The optimized method was validated as per ICH guidelines. The developed method was also applied to pharmaceutical formulations for the determination of paliperidone and its related substances.

\subsection{Validation}

3.4.1. Specificity (Selectivity). The data on degradation studies revealed that the degradation products were well separated from the paliperidone and the peak purity data (purity angle is less than purity threshold) of paliperidone indicated that itwas spectrally pure. The mass balance is a process of adding together the assay value and the levels of degradation products to see how closely these add up to $100 \%$ of initial value with due consideration of the margin of analytical error [18]. The mass balance of stressed samples was close to $99.9 \%$. The data on forced degradation studies is given in Table 3 . 


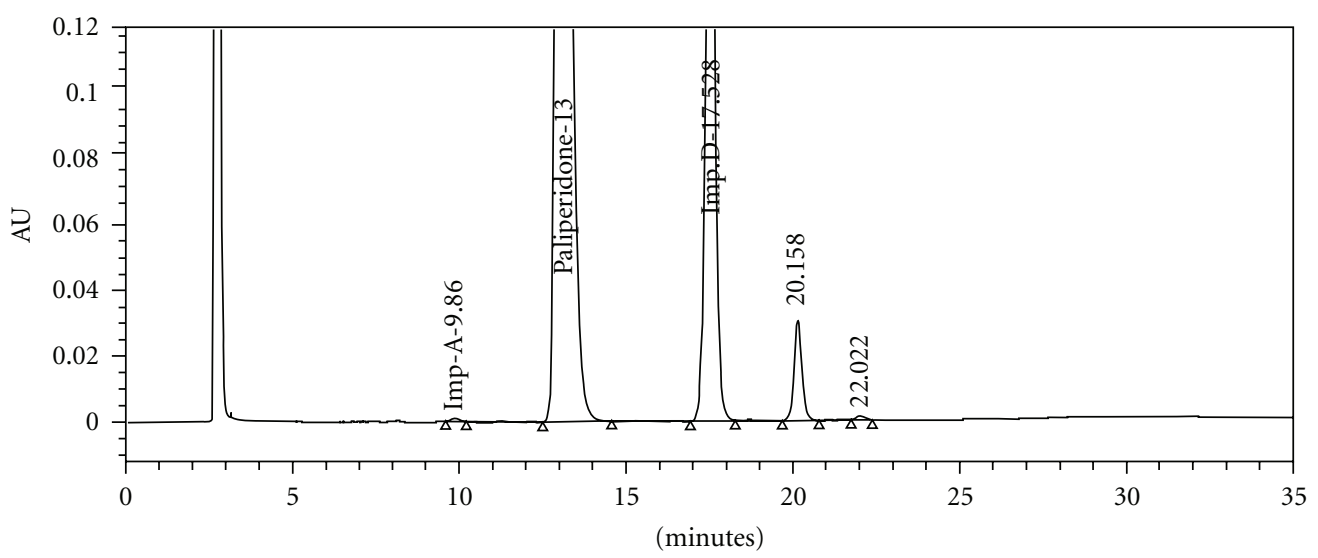

(a) Peroxide-treated test sample

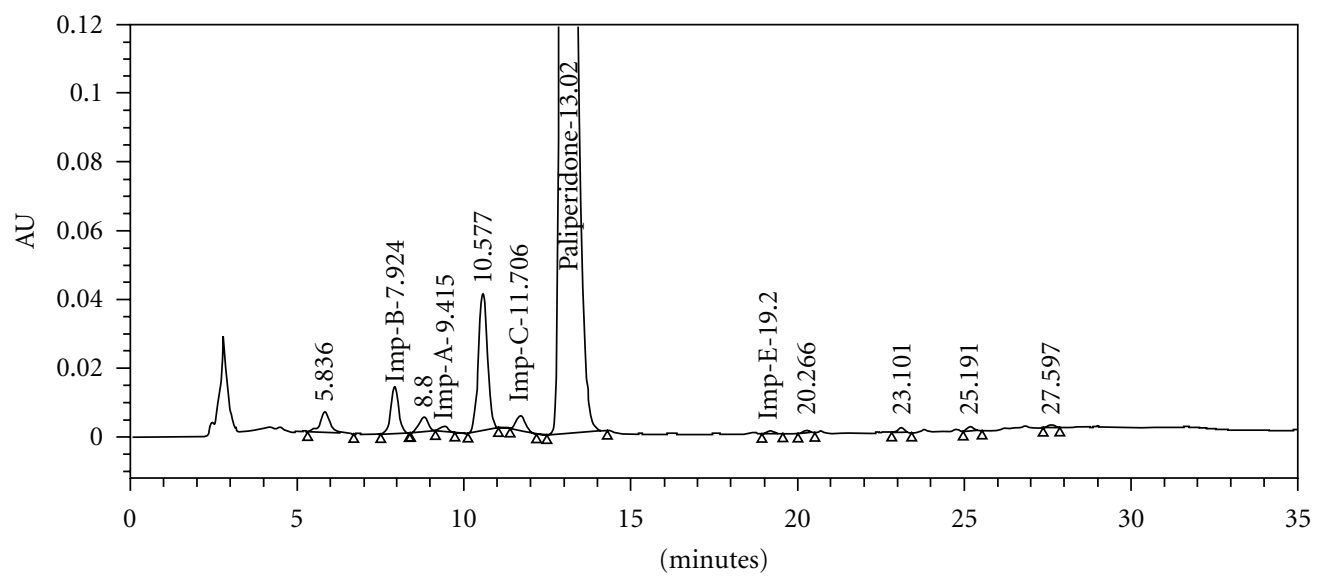

(b) Base-treated test sample

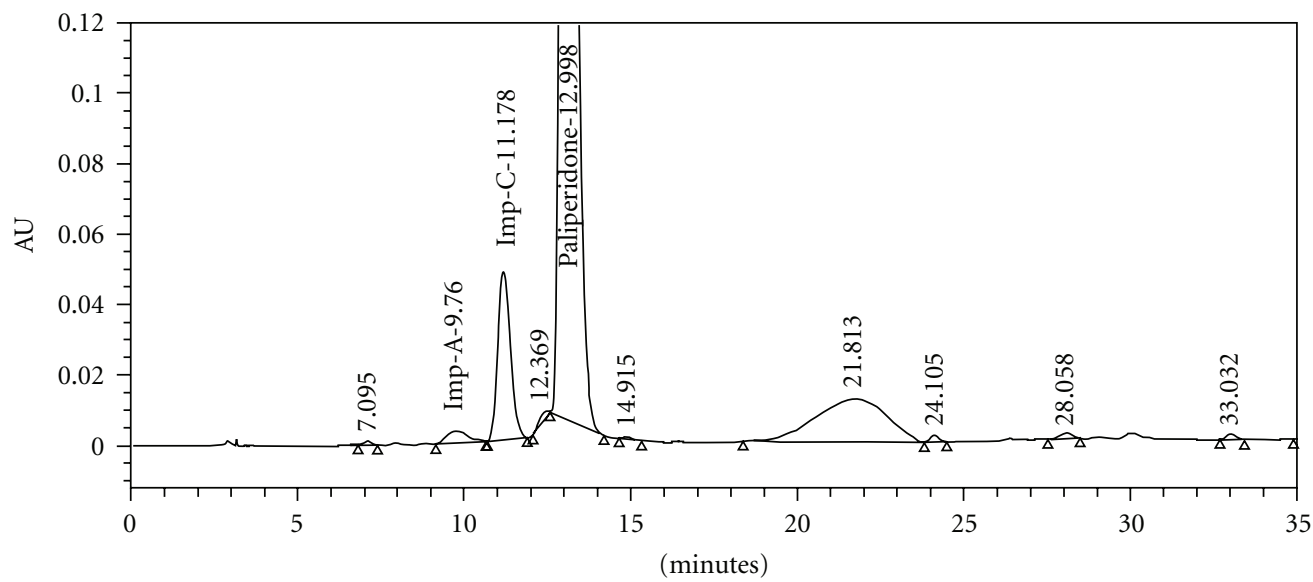

(c) Acid-treated test sample

FIGURE 3: Typical RP-HPLC chromatograms of forced degradation; (a) peroxide treated test sample and (b) acid treated test sample, (c) base treated test sample.

3.4.2. Linearity. The linearity of method was established at two different levels. The assay linearity was studied by preparing five different solid weightings of paliperidone from 50 to $150 \% \mathrm{w} / \mathrm{w}(50,75,100,125$, and $150 \% \mathrm{w} / \mathrm{w})$ with respect to target analytical concentration $\left(100 \mu \mathrm{g} \mathrm{mL}^{-1}\right)$ and injected. Linearity test solutions for related substance were prepared by diluting the impurity stock solution (as described in the section of Analytical Procedure) to the required concentrations. The solutions were prepared at six concentration levels from LOQ to 250\% (LOQ, 50, 100, 150,200 and $250 \%$ ) with respect to the specification level of impurities. The data were subjected to statistical analysis using a linear-regression model; the regression equations and correlation coefficients are given in Table 4 . 
TABLE 4: Validation data results of related substances and assay of paliperidone.

\begin{tabular}{|c|c|c|c|c|c|c|}
\hline \multirow{2}{*}{ Compound } & \multicolumn{5}{|c|}{ Related substances results } & \multirow{2}{*}{$\begin{array}{l}\text { Assay results } \\
\text { paliperidone }\end{array}$} \\
\hline & IMP-A & IMP-B & IMP-C & IMP-D & IMP-E & \\
\hline \multicolumn{7}{|l|}{ Precision (mean results $\pm \%$ RSD) } \\
\hline Method precision $(n=6)$ & $\begin{array}{l}0.164 \pm \\
1.24\end{array}$ & $\begin{array}{c}0.163 \pm \\
0.61\end{array}$ & $\begin{array}{l}0.546 \pm \\
3.85\end{array}$ & $\begin{array}{c}0.149 \pm \\
0.67\end{array}$ & $\begin{array}{c}0.059 \pm \\
1.69\end{array}$ & $99.0 \pm 0.21$ \\
\hline Intermediate Precision $(n=6)$ & $\begin{array}{c}0.158 \pm \\
0.63\end{array}$ & $\begin{array}{c}0.159 \pm \\
0.00\end{array}$ & $\begin{array}{c}0.526 \pm \\
0.57\end{array}$ & $\begin{array}{l}0.151 \pm \\
0.66\end{array}$ & $\begin{array}{c}0.062 \pm \\
0.00\end{array}$ & $100.3 \pm 0.35$ \\
\hline Overall results $(n=12)$ & $\begin{array}{l}0.160 \pm \\
1.25 \\
\end{array}$ & $\begin{array}{l}0.161 \pm \\
1.24 \\
\end{array}$ & $\begin{array}{l}0.536 \pm \\
3.39 \\
\end{array}$ & $\begin{array}{l}0.150 \pm \\
1.33 \\
\end{array}$ & $\begin{array}{c}0.061 \pm \\
3.28 \\
\end{array}$ & $99.7 \pm 0.75$ \\
\hline \multicolumn{7}{|l|}{ Limit of detection (LOD) } \\
\hline $\mathrm{LOD}\left(\mu \mathrm{g} \mathrm{mL}^{-1}\right)$ & 0.030 & 0.039 & 0.155 & 0.071 & 0.046 & 0.065 \\
\hline LOD (\% w.r.t. test) & 0.003 & 0.004 & 0.016 & 0.007 & 0.005 & 0.007 \\
\hline \multicolumn{7}{|l|}{ Limit of quntitations (LOQ) } \\
\hline $\operatorname{LOQ}\left(\mu \mathrm{g} \mathrm{mL}^{-1}\right)$ & 0.090 & 0.119 & 0.470 & 0.214 & 0.141 & 0.197 \\
\hline LOQ (\% w.r.t. test) & 0.009 & 0.012 & 0.047 & 0.021 & 0.014 & 0.020 \\
\hline \multicolumn{7}{|c|}{ Linearity: for related substances LOQ to $250 \%$ of specification level and for assay 50 to $150 \%$ of TAC } \\
\hline Correlation coefficient $(r)$ & 0.99966 & 0.99978 & 0.99973 & 0.99936 & 0.99925 & 0.99996 \\
\hline Slope & 22910.49 & 35819.23 & 19598.94 & 30803.29 & 36086.78 & 31580.49 \\
\hline Intercept & -100.38 & -653.37 & 1214.32 & -172.37 & -631.62 & -1131.83 \\
\hline \multicolumn{7}{|c|}{ Accuracy (mean recovery $\pm \%$ RSD): LOQ to $150 \%$ of specification level } \\
\hline LOQ & $\begin{array}{l}92.59 \pm \\
6.93\end{array}$ & $\begin{array}{l}86.11 \pm \\
5.59\end{array}$ & $\begin{array}{c}106.51 \pm \\
7.36\end{array}$ & $\begin{array}{l}90.48 \pm \\
5.27\end{array}$ & $\begin{array}{l}92.31 \pm \\
8.33\end{array}$ & - \\
\hline $50 \%$ & $\begin{array}{l}93.86 \pm \\
2.14\end{array}$ & $\begin{array}{l}95.22 \pm \\
0.75\end{array}$ & $\begin{array}{c}114.93 \pm \\
1.04\end{array}$ & $\begin{array}{c}100.00 \pm \\
1.35\end{array}$ & $\begin{array}{c}91.11 \pm \\
1.69\end{array}$ & - \\
\hline $100 \%$ & $\begin{array}{c}104.17 \pm \\
1.93\end{array}$ & $\begin{array}{c}97.60 \pm \\
0.77\end{array}$ & $\begin{array}{c}107.54 \pm \\
0.68\end{array}$ & $\begin{array}{c}99.55 \pm \\
1.42\end{array}$ & $\begin{array}{c}94.67 \pm \\
0.70\end{array}$ & - \\
\hline $150 \%$ & $\begin{array}{c}103.36 \pm \\
0.65\end{array}$ & $\begin{array}{c}97.68 \pm \\
0.51\end{array}$ & $\begin{array}{c}104.37 \pm \\
0.44\end{array}$ & $\begin{array}{c}99.85 \pm \\
1.44\end{array}$ & $\begin{array}{c}94.81 \pm \\
0.54\end{array}$ & - \\
\hline
\end{tabular}

$\%$ w.r.t. test LOD LOQ values are in \% with respect to test concentration of $1000 \mu \mathrm{g} \mathrm{mL}-1$.

TAC, Target analytical concentration that is, $100 \mu \mathrm{g} \mathrm{mL}^{-1}$.

The RF of each impurity was determined using the slope of the paliperidone plot against each impurity plot. The Yintercept of each plot was within the $2.5 \%$ of the response at $0.15 \% \mathrm{w} / \mathrm{w}$ level of each impurity, describing that the plot is going almost through the origin.

3.4.3. Limits of Detection and Quantitation (LOD and LOQ). The limit of detection and limit of quantitation were determined for paliperidone and for each of the related substances as per ICH Q2R1 guideline from the standard deviation of the peak areas and slope of linearity data. The values of LOD and LOQ for paliperidone were $0.065 \mu \mathrm{g} \mathrm{mL} L^{-1}$, $0.197 \mu \mathrm{g} \mathrm{mL}^{-1}$ and they were for related substances, in the ranges, $0.030-0.155 \mu \mathrm{g} \mathrm{mL}^{-1}$ and $0.090-0.470 \mu \mathrm{g} \mathrm{mL}^{-1}$ respectively. The calculated LOQ concentrations of all the components were verified for precision by injecting six individual preparations of Imp-A, Imp-B, Imp-C, Imp-D, Imp-E, and paliperidone. The RSD of LOQ precision was in the range of $1.22-9.78 \%$. These limits of quantification levels of the impurities were helpful for the process research work to control the impurities at the accepted level during the optimization of the process. The results were depicted in Table 4.
3.4.4. Precision. System precision for assay method was verified by injecting the six replicate injections of standard concentration $\left(50 \mu \mathrm{g} \mathrm{mL}^{-1}\right)$, and RSD of paliperidone peak area was evaluated and found to be $0.20 \%$. System precision for related substances determination was verified by system suitability solution, which was analyzed for six times, and RSD of paliperidone and all impurities peak areas was evaluated and found to be $2.04 \%$.

Precision of the method was studied for method precision and intermediate precision. The assay method precision was examined by analysing six determinations of the sample solution at working concentration versus a standard concentration, and RSD of obtained results was evaluated and found to be $0.21 \%$. Related substances method precision was demonstrated by analyzing six separate paliperidone sample solutions that were prepared by spiking the related substances namely, Imp-A, Imp-B, Imp-C, and Imp-D at specification level. The RSD $(0.61-3.85 \%, n=6)$ for each related substance was evaluated. In the intermediate precision study, the similar procedure of method precision was carried out by a different analyst, using different mobile phase and diluent preparations and instrument on a different 
TABLE 5: Results (in \%) of formulation tablet and bulk drug batches sample analysis.

\begin{tabular}{|c|c|c|c|c|c|c|}
\hline Sample source & Imp-A & Imp-B & Imp-C & Imp-D & Imp-E & SMUI \\
\hline \multicolumn{7}{|c|}{ Formulation product analysis results } \\
\hline Formulation-1 & ND & ND & 0.19 & 0.01 & ND & 0.02 \\
\hline Formulation-2 & ND & ND & 0.19 & 0.01 & ND & 0.02 \\
\hline \multicolumn{7}{|c|}{ Batch analysis results (\%) } \\
\hline B.NO.1 & 0.02 & ND & 0.06 & ND & 0.05 & ND \\
\hline B.NO.2 & 0.02 & 0.01 & 0.06 & ND & 0.06 & ND \\
\hline B.NO.3 & 0.02 & ND & 0.06 & ND & 0.06 & ND \\
\hline
\end{tabular}

ND, not detected; SMUI, single maximum unknown impurity.

day with different lot of same brand column. The percentage relative standard deviation of the results for assay method and related substances method was evaluated and found to be $0.35 \%$ and $2.0-3.0 \%$, respectively. The results were reported in Table 4.

3.4.5. Accuracy (Recovery). Accuracy of the method for all the related substances was determined by analyzing paliperidone sample solutions spiked with all the related substances at four different concentration levels of LOQ, 50, 100 , and $150 \%$ of each in triplicate at the specified limit. The recovery of all these related substances were found to be in between the predefined acceptance criterion of $80.0-120.0 \%$, and the data is given in Table 4 .

3.4.6. Stability of Analytical Solution. To determine the stability of sample solution, the sample solutions of paliperidone spiked with related substances at specified level were prepared and analyzed immediately after preparation and after different time intervals up to 8 days, while maintaining the sample cooler temperature at about $25^{\circ} \mathrm{C}$ and at about refrigerator temperature $\left(5-8^{\circ} \mathrm{C}\right)$. The results from these studies indicated the sample solution was unstable at room temperature and stable for 8 days at $8^{\circ} \mathrm{C}$ temperature.

3.4.7. Mobile Phase Stability. To evaluate the mobile phase stability of the method, the paliperidone test sample spiked with related substances at specification level was used. The paliperidone test sample was analyzed after $24 \mathrm{hrs}$ and after $48 \mathrm{hrs}$ by using same mobile phase. The content of each impurity was evaluated and compared to the mean results of method precision. The difference between the mean values (after 48 hrs.) from the method precision mean results is found to be below $10.0 \%$. The studies indicated no effect on the determination of related substances and the selectivity after $48 \mathrm{hrs}$. Therefore the mobile phase is stable for $48 \mathrm{hrs}$.

3.4.8. Robustness. To evaluate the robustness of the developed method, the chromatographic conditions were deliberately altered and the resolution between closely eluting peak pair that is, Imp-C and paliperidone was evaluated. The flow rate of the mobile phase was $1.0 \mathrm{~mL} \mathrm{~min}^{-1}$. To study the effect of flow rate on the resolution, the same was altered by 0.1 units that is, from 0.9 to $1.1 \mathrm{~mL} \mathrm{~min}^{-1}$. The effect of column temperature on resolution was studied at 42 and $48^{\circ} \mathrm{C}$ instead of $45^{\circ}$. All the other mobile phase components were held constant as described above. In all the deliberate varied chromatographic conditions (flow rate and column temperature), the tailing factor of paliperidone was less than 1.20 and the resolution between any two peaks was greater than 2.0. There was a very minor variation in the resolution and tailing factor results observed in all the robustness conditions, illustrating the robustness of the method.

3.4.9. Application of the Method. The analysis of commercial formulation sample and bulk drug sample indicates that the method is specific and selective for determination of related substances in the formulation and bulk drug samples (Table 5). The developed method is capable of quantitative analysis of paliperidone in the bulk drug and in a pharmaceutical dosage form.

\section{Conclusion}

The method presented in this communication describes the development of a rapid, simple, accurate, and selective gradient RP-HPLC method that separates the all related substances with good resolution. The process, and degradation related impurities, which were present in paliperidone sample were identified by LC-MS and characterized using MS, FT-IR, and ${ }^{1}$ HNMR spectral data. The developed method was validated to ensure the compliance in accordance with ICH guidelines. The method was found to be simple, selective, precise, accurate, and robust. Therefore, this method can be used for routine testing as well as stability analysis of paliperidone drug substance. All statistical results (percentage, mean, R.S.D., percentage difference, and recovery \%) were within the acceptance criteria. The method could be of use not only for routine evaluation of the quality of paliperidone in bulk drug manufacturing unit but also for detection of impurities in pharmaceutical formulations.

\section{Acknowledgments}

The authors wish to thank the management of Megafine group for supporting this paper. The authors would also like to thank colleagues in the division of Research and Development of Megafine Pharma (P) Ltd. for their cooperation in carrying out this paper. 


\section{References}

[1] A. Schotte, P. F. M. Janssen, W. Gommeren et al., "Risperidone compared with new and reference antipsychotic drugs: in vitro and in vivo receptor binding," Psychopharmacology, vol. 124, no. 1-2, pp. 57-73, 1996.

[2] A. A. H. P. Megens and F. H. L. Awouters, "In vivo pharmacological profile of 9-hydroxyrisperidone, the major metabolite of the novel antipsychotic risperidone," Drug Development Research, vol. 33, no. 4, pp. 399-412, 1994.

[3] N. Yasui-Furukori, M. Hidestrand, E. Spina, G. Facciola, M. G. Scordo, and G. Tybring, "Different enantioselective 9hydroxylation of risperidone by the two human CYP2D6 and CYP3A4 enzymes," The American Society for Pharmacology and Experimental Therapeutics, vol. 29, no. 10, pp. 1263-1268, 2001.

[4] S. Tianmei, S. Liang, L. Yi, S. Yun'Ai, G. Chunmei, and Z. Hongyan, "Single-dose pharmacokinetics of paliperidone extended release tablets in healthy Chinese subjects," Human Psychopharmacology: Clinical and Experimental, vol. 25, no. 5, pp. 404-409, 2010.

[5] M. P. Corena-McLeod, A. Oliveros, C. Charlesworth et al., "Paliperidone as a mood stabilizer: a pre-frontal cortex synaptoneurosomal proteomics comparison with lithium and valproic acid after chronic treatment reveals similarities in protein expression," Brain Research, vol. 1233, pp. 8-9, 2008.

[6] G. Marchese, B. Pittau, G. Casu et al., "A comparison of continuous subcutaneous paliperidone infusion and repeated subcutaneous injection of risperidone free-base in rats," European Psychiatry, vol. 25, no. 2, pp. 92-100, 2010.

[7] R. Arakawa, H. Ito, A. Takano et al., "Dose-finding study of paliperidone ER based on striatal and extrastriatal dopamine $\mathrm{D}_{2}$ receptor occupancy in patients with schizophrenia," Psychopharmacology, vol. 197, no. 2, pp. 229-235, 2008.

[8] Product Monograph, "Paliperidone, Extended release tablets $3 \mathrm{mg}, 6 \mathrm{mg}$ and $9 \mathrm{mg}$, http://www.janssen-ortho.com/JOI/pdf files/Invega_E.pdf.

[9] M. Vermeir, I. Naessens, B. Remmerie et al., "Absorption, metabolism, and excretion of paliperidone, a new monoaminergic antagonist, in humans," The American Society for Pharmacology and Experimental Therapeutics, vol. 36, no. 4, pp. 769-779, 2008.

[10] R. B. Patel, M. R. Patel, K. K. Bhatt, and B. G. Patel, "HPTLC method development and validation: quantification of paliperidone in formulations and in vitro release study," Analytical Methods, vol. 2, pp. 525-531, 2010.

[11] B. Cabovska, S. L. Cox, and A. A. Vinks, "Determination of risperidone and enantiomers of 9-hydroxyrisperidone in plasma by LC-MS/MS," Journal of Chromatography B, vol. 832, no. 1-2, pp. 497-504, 2007.

[12] R. Woestenborghs, W. Lorreyne, F. Van Rompaey, and J. Heykants, "Determination of risperidone and 9-hydroxyrisperidone in plasma, urine and animal tissues by highperformance liquid chromatography," Journal of Chromatography, vol. 583, no. 2, pp. 223-230, 1992.

[13] "Impurities in new drug substances," in Proceedings of the International Federation of Pharmaceutical Manufactures \& Associations (IFPMA '06), International Conference on Harmonization (ICH), Geneva, Switzerland, October 2006, Methodology Q3A(R2).
[14] "Good manufacturing practice guide for active pharmaceutical ingredients," in Proceedings of the International Federation of Pharmaceutical Manufactures \& Associations (IFPMA '05), International Conference on Harmonization (ICH), Geneva, Switzerland, November 2005, Methodology Q7A.

[15] The United States Pharmacopeia, Validation of Compendial Methods, section 1225, The United States Pharmacopeia (USP), Rockville, Md, USA, 32nd edition, 2009.

[16] "Validation of analytical procedure," in Proceedings of the International Federation of Pharmaceutical Manufactures \& Associations (IFPMA '96), International Conference on Harmonization (ICH), Geneva, Switzerland, November 1996, Methodology Q2(R1).

[17] J. Ruan, P. Tattersall, R. Lozano, and P. Shah, "The role of forced degradation studies in stability indicating HPLC method development," American Pharmaceutical Review, vol. 9, no. 1, pp. 46-53, 2006.

[18] M. Bakshi and S. Singh, "Development of validated stability-indicating assay methods-critical review," Journal of Pharmaceutical and Biomedical Analysis, vol. 28, no. 6, pp. 1011-1040, 2002.

[19] H. C. Juan and C. M. Noelia, "Process to prepare paliperidone and intermediates thereof," PCT Pat., WO 2009/144288 A1, 2009.

[20] R. L. Snyder, J. Kirkland, and L. Glajch, Practical LC Method Development, Jonh Wiley \& Sons, Hoboken, NY, USA, 1997.

[21] R. LoBrutto, A. Jones, Y. V. Kazakevich, and H. M. McNair, "Effect of the eluent $\mathrm{pH}$ and acidic modifiers in highperformance liquid chromatography retention of basic analytes," Journal of Chromatography A, vol. 913, no. 1-2, pp. 173-187, 2001. 


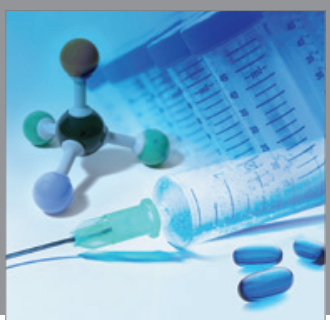

International Journal of

Medicinal Chemistry

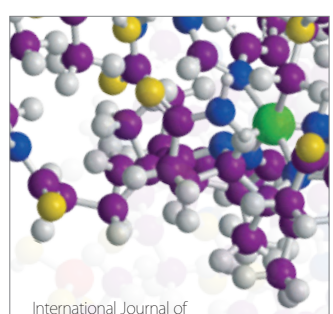

Carbohydrate Chemistry

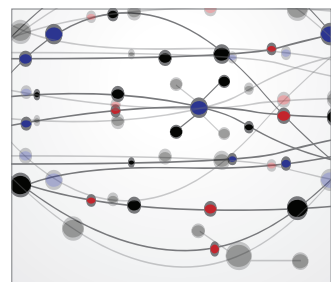

The Scientific World Journal
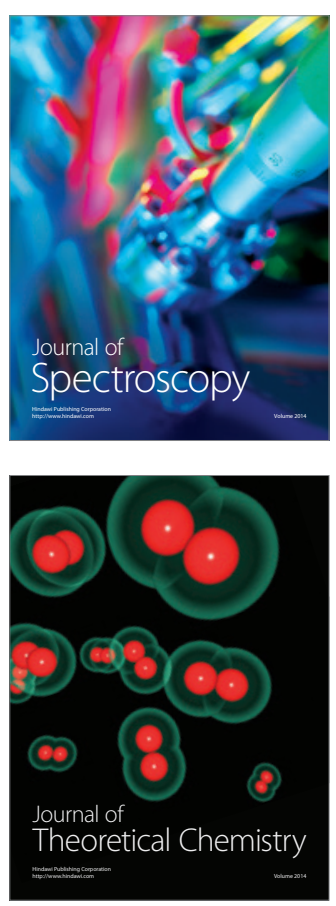
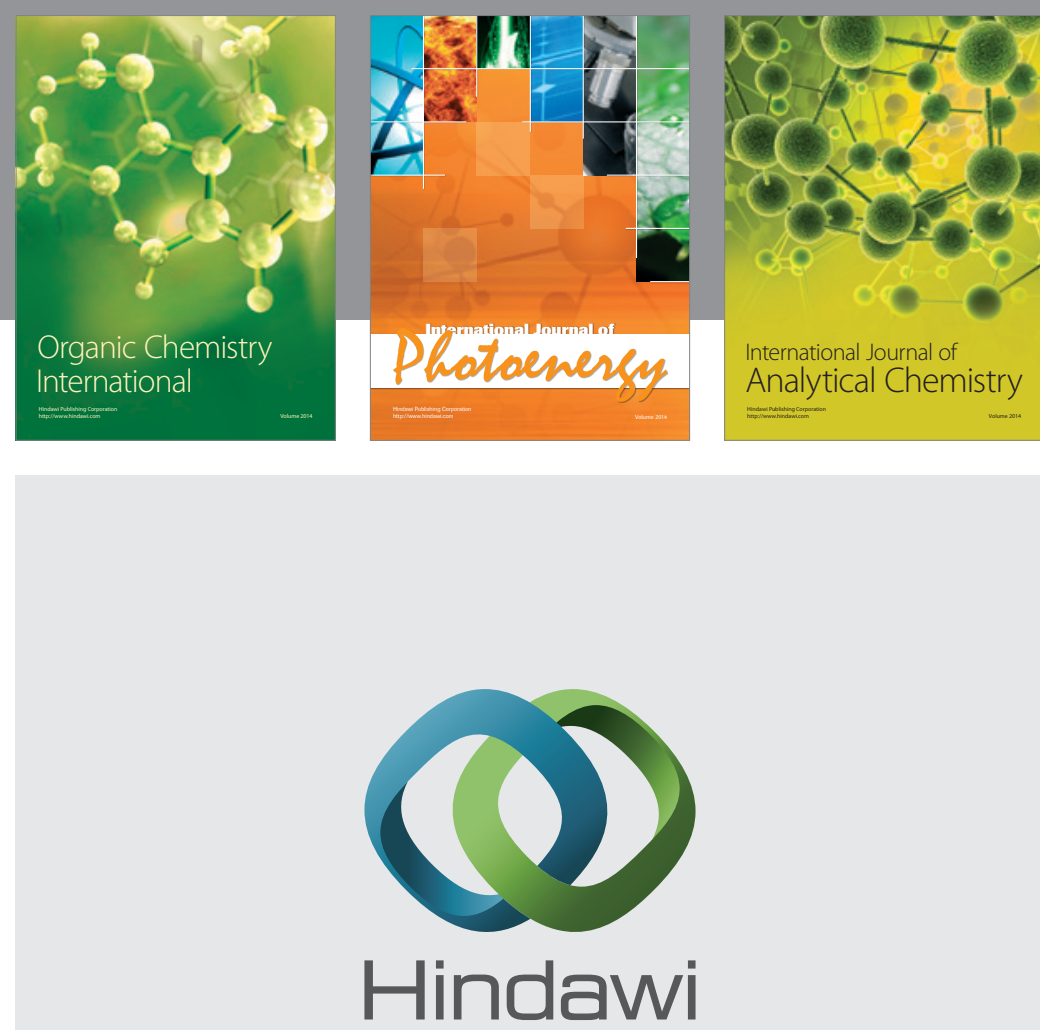

Submit your manuscripts at

http://www.hindawi.com
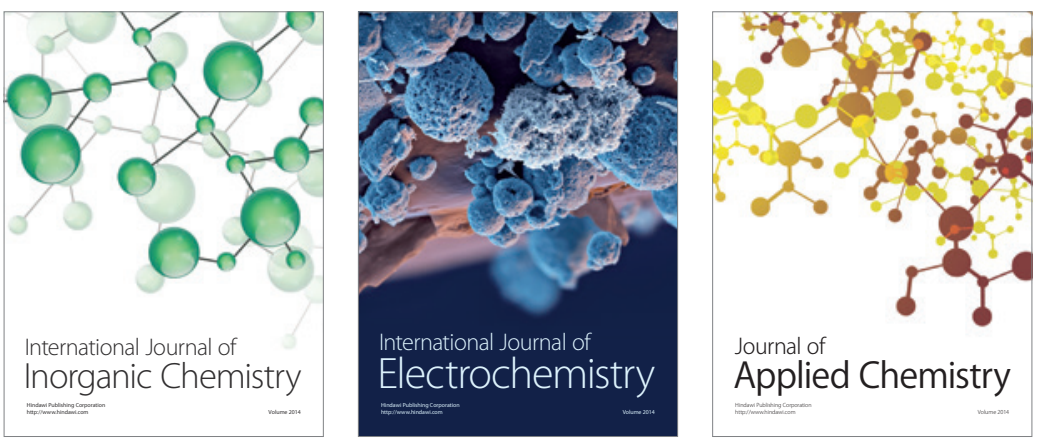

Journal of

Applied Chemistry
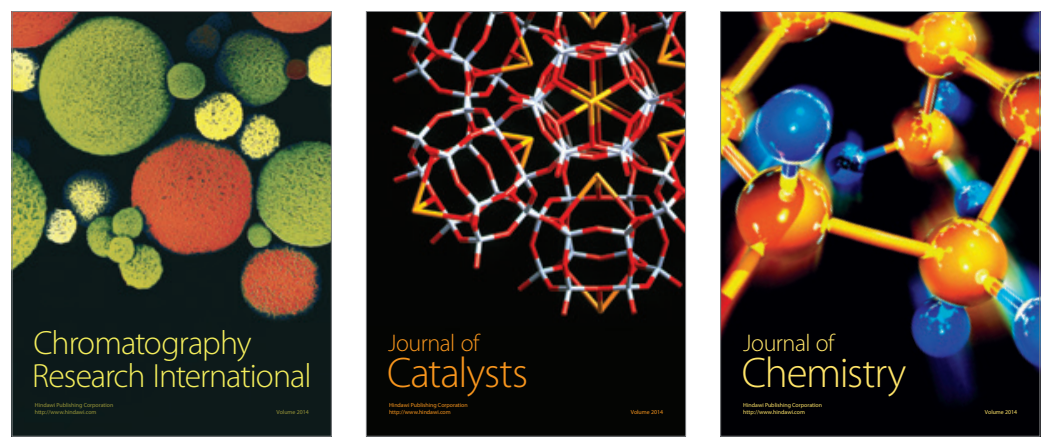
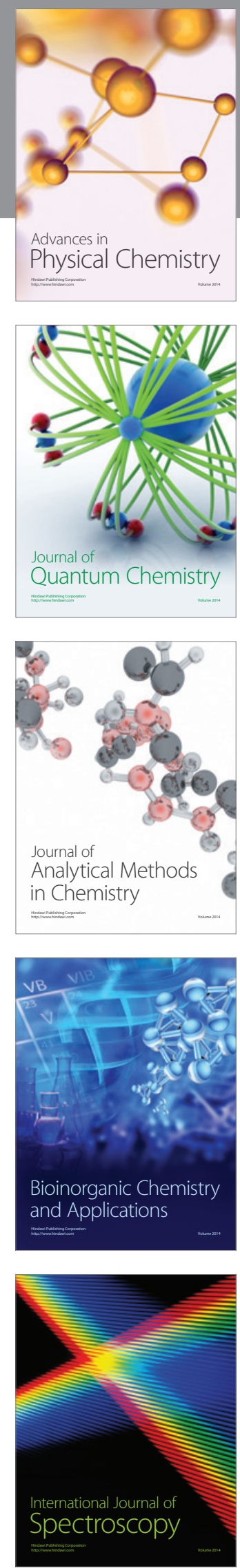